\title{
Quantifying Audit Expectation Gap: A New approach to Measuring Expectation Gap
}

\author{
Mahdi Salehi*
}

\begin{abstract}
The main objective of the study is at first identifying the expectation gap about audit responsibility and the second quantifying the expectation gap in Iran.In order to collecting data, a questionnaire designed and developed between auditors and investors. Collected data analyzed by employing non-parametric statistics test. The results show that there is expectation gap between auditors and investors in Iran. The current study employed a new approach in the world in order to quantifying the expectation gap. It gives the more strength to other researchers in order to measuring audit expectation gap in the world.
\end{abstract}

Keywords: Audit expectation gap, Audit responsibility, quantifying audit expectation gap

JEL Classification: M, M00

\section{Introduction}

Many users misunderstand the nature of the attest function, especially in the context of an unqualified opinion. Some users believe that an unqualified opinion means that the entity has foolproof financial reporting. Some feel that the auditor should not only provide an audit opinion, but also interpret the financial statements in such a manner that the user could evaluate whether to invest in the entity. There are also users who expect auditors to perform some of the audit procedures while performing the attest function like penetrating into company affairs, engaging in management surveillance and detecting illegal acts and/or fraud on the part of management. It is these high expectations on the part of users of financial statements that create a gap between auditors' and users' expectations of the audit function. In addition, the users also place the responsibility for narrowing the gap on auditors and others involved in preparing and presenting financial statements.

\footnotetext{
* Mahdi Salehi is at Ferdowsi University of Mashhad, Mashhad, Islamic Republic of Iran (e-mail: mehdi.salehi@um.ac.ir).
} 
Various studies have confirmed the existence of the audit expectation gap. Prior literature in audit expectation gap evinces that the expectations gap between auditors and financial statement users has existed for the past hundred years. The audit expectation gap has become a topic of considerable interest worldwide, for research in general, and in the advanced countries like the U.S, the U.K, New Zealand, Germany and Singapore in particular for the last thirty years. This is due to the occurrence of series of corporate failures, financial scandals and audit failures in these advanced countries and their subsequent impact on other countries' audit profession. The literature available on audit expectation gap and related matters evinces the extent to which the auditing environment has become litigious.

The widespread criticism of and litigation against auditors indicates that there is a gap between society's expectations of auditors and auditor's performance as perceived by society. The majority of research studies indicate that the audit expectation gap is mainly due to users' reasonable expectations of audits as well their as unrealistic perceptions of the audit profession's performance. According to these studies, the differences may be attributable to users' misunderstanding of what is reasonably expected from an audit, and of the actual quality of the audit work. Although a number of explanations for the existence and persistence of the audit expectation gap appear in the literature, references to users' misunderstandings of the role, objectives and limitations of an audit, inadequate audit standards and deficient auditor performance capture the main essence of its causes. This results in users' dissatisfaction with auditor's performance that undermines confidence in the auditing profession and the external audit function.

\section{Audit Expectation Gap}

The term 'expectation gap' is commonly used to describe the situation whereby a difference in expectation exists between a group with a certain expertise and a group, which relies upon that expertise. The public perception of an auditor's responsibility differs from that of the profession and this difference is referred to as the expectation gap. The term has been used not only in the accounting literature, but also in other fields, for example, to describe the perceptions of the information systems industry relating to the academic preparation of graduates (Trauth et al., 1993); difference in expectations of advertising agencies and their clients with respect to campaign values (Murphy and Maynard, 1996); differences in relation to various issues associated with corporate environmental reporting on one hand and the clash between auditors and the public over preferred meanings of the nature, objectives and outcomes of an audit (Sikka et al., 1998) and (Deegan and Rankin, 1999); the gap in banks between the transaction-audit approach that evolved during the industrial age and the information age (Singh, 2004); and a financial reporting expectation gap (Higson, 2003). 
Most of the times, financial statement users consider an auditor's report to be a clean bill of health. Thus, most users' expectation towards auditors is far more than what it should be. Expectation gap occurs when there are differences between what the public expects from the auditor and what the auditor actually provides. The expectation gap is the gap between the auditor's actual standard of performance and the various public expectations of auditor performance. According to Percy (2007) Public expects that: (a) the accounts are right; (b) companies will not fail; (c) companies will guard against fraud and error; (d) companies will act within the law; (e) companies will be competently managed; and (f) companies will adopt a responsible attitude to environmental and societal matters. However, the concept of audit expectation gap is writ large with many issues. Hence, the concept has been delineated below under (i) Genesis of the Concept; (ii) Definitions; (iii) The Rising Gap; (iv) Target Groups and (v) The Sources and Components.

\section{Genesis of the Concept}

The term audit expectation gap emerged during the 1970s (Humphrey et al., 1993). For the last thirty years, audit expectation gap has become the topic of considerable interest to worldwide contemporary in the area propelled by litigious audit environment. However, this is not surprising given that the expectations gap between auditors and financial statement users has existed for the past hundred years (Humphrey et al., 1993).

\section{Definitions}

The most relevant definitions on audit expectation gap are presented below:

Liggio (1974) defines it as the difference between the levels of expected performance as envisioned by the independent accountant and by the user of financial statements.

The Cohen Commission (1978) on auditors' responsibility extended this definition by considering whether a gap may exist between what the public expects or needs and what auditors can and should reasonably expect to accomplish.

According to Guy and Sullivan (1988), there is a difference between what the public and financial statement users believe accountants, auditors are responsible for, and what the accountants and auditors themselves believe they are responsible.

Godsell (1992) described the expectation gap as "which is said to exist, when auditors and the public hold different beliefs about the auditors' duties and responsibilities and the messages conveyed by audit reports."

Jennings et al. (1993), in their study on the use of audit decision aids to improve auditor adherence to a 'standard', are of the opinion that the audit expectations gap is 
the difference between what the public expects from the auditing profession and what the profession actually provides.

Monroe and Woodliff (1993:62) defined audit expectation gap as "the difference in beliefs between auditors and public about the duties and responsibilities assumed by auditors and the messages conveyed by audit reports."

According to AICPA (1993), the 'audit expectation gap' refers to the difference between (1) what the public and financial statement users believe the responsibilities of auditors to be; and (2) what auditors believe their responsibilities are.

Epstein and Geiger (1994) defined audit expectation gap as: differences in perceptions especially regarding assurances provided between users, preparers and auditors.

The ASCPA and ICAA (1994:3) observe that the term 'expectation gap' should be used to describe "...the difference between expectations of the users of financial reports and the perceived quality of reporting and auditing services delivered by the accounting profession."

A perusal of these definitions reveals that the expectation gap may refer to any one or all of the following: (i) difference in perceptions on actual performance and expected performance of auditors; and (ii) existence of these perceptional differences in auditors, accountants or users of financial statements and the society independently and comparatively. At present, the focus of comparative analysis of audit expectation gap is attempted by considering the perceptions of (i) society and auditors; (ii) accountants and auditors; and (iii) investors and auditors simultaneously.

Most users' expectations towards auditors are far more than what it should be and it arises when there are differences between what the public expects from the auditor and what the auditor actually provides. Tweedie (1987) set out the extent of the problem as follows: "The public appears to require (1) a burglar alarm system (protection against fraud) (2) a radar station (early warning of future insolvency) (3) a safety note (general reassurance of financial well-being) (4) an independent auditor (safeguards for auditor independence) and (5) coherent communications (understanding of audit reports)". To guarantee an efficient control to the shareholders and to the general public, the auditors have to meet stringent requirements both with regard to their professional knowledge and with regard to their independence on these lines: (i) auditors should be accepting prime responsibility for the financial statements, that they certify financial statements; (ii) A clean opinion guarantees the accuracy of financial statements, that auditors perform a cent per cent check; (iii) Auditors should be given early warning about the possibility of business failure; and (iv) Auditors are supposed to detect fraud. Such public expectations of auditors, which go beyond the actual standard of performance by auditors, have led to the "expectation gap". 


\section{The Rising Gap}

The interest in audit expectation gap is of recent origin in empirical research of Darnill (1991) attributes to this slow pace of interest in it as a general lack of public interest in the work of the auditor. However, Tricker (1982) observes that the expectations gap represented as the result of a natural time lag in the auditing profession identifying and responding to continually evolving and expanding public expectations.

The studies by Dejong et al., (1984) and Hooks (1992) emphasize that the profession's refusal of performing the fraud detection duties had fuelled the expectation gap. Hence, the interest in audit expectation gap is propelled by the recent corporate failures, which are essentially the result of fraudulent audit processes evidenced in the scandals of Enron, WorldCom, and Texaco etc. The failure to check the frauds and preventing the impending bankruptcies through an effective audit program has culminated in the interest on audit expectation gap in recent years. Further, Kelly and Mohrweis (1989) observe that judicial litigants often appear to apply as a standard, the concept that an audit is a comprehensive check on a corporation's financial activities. As a result, the audit expectation gap has occupied the prime position in financial reporting arena. However, a business failure is often interpreted to be an audit failure regardless of the level of procedures and tests performed by the auditor. Further, Sikka et al. (1992) contend that the 'expectation gap' is an outcome of the contradiction of minimum government regulation and the profession's self-regulation, especially, the profession's over-protection of self-interest, which has widened the 'expectation gap', this statement is also supported by Giacomino (1994); and Chandler and Edwards (1996).

Martinis et al. (2000) view audit expectation gap by examining the extent to which lower levels of user cognizance of the role, objectives and limitations of an audit are associated with unreasonable audit expectations and perceptions. It found that the audit expectation gap prevailed where respondents had relatively little business work experience and no university qualifications. To conclude, the much-quoted statement by Humphrey (1991) as to whether the auditor is 'a watchdog or a bloodhound' continues to be the central issue in audit expectation gap.

Recently in Iran, Pourheydari and Abousaiedi (2011) conducted a study about audit expectation gap. The results of the study revealed that there is expectation gap in the areas of auditor responsibility for fraud detection, soundness of the internal controls, and preparation of financial statements. Further, the found that no significant difference between users and independent auditors regarding the reliability and utility of audited financial statements. In order to, reducing the gap they suggested that through improvement in auditor-user communication in the audit reports as well as educating users on the nature and functions of audits, the gap may reduced. 


\section{Target Groups}

Leaving apart the society as a target group to analyze the perceptional differences on audit expectation gap by the researchers there is widespread difference in identification of the target groups for the study.

In the early years of research on audit expectation gap, Bailey et al. (1983), for example, studied the problem from the viewpoint of more knowledgeable users and less knowledgeable users with the premise that auditors were more knowledgeable than the public.

Singleton (1990) too confirmed that there was an expectation gap between the profession and the users of accounts. However, one of their interesting findings was that there was also an expectation gap within the profession because accountants themselves lost sight of what they are trying to do with accounts.

Monroe and Woodliff (1994) were also of the same opinion that there were significant differences between the auditors and each of the user groups. In their study, they considered auditors as the most sophisticated group, the accountants, creditors and directors as the intermediate group and the shareholders and students were considered the least sophisticated group. There were significant differences between the user groups with the creditors and accountants being significantly higher than the directors, students and shareholders.

Beelde et al. (1999) identified that perceptions existed in internal auditors and external audits. The aim was to find out whether certain perceptions could be associated with a certain target group and whether the perceptions between the various target groups differ.

To conclude, the target groups used in the research on audit expectation gap have varied significantly and there seems to be no final answer to the target groups.

\section{The Sources and Components}

The expectation gap has been attributed to many numbers of different causes:

- The probabilistic nature of auditing.

- The ignorance, naivety, misunderstanding and unreasonable expectations of non-auditors about the audit function;

- The evaluation of audit performance based upon information or data not available to the auditor at the time the audit was completed;

- The evolutionary development of audit responsibilities, which creates time lags in responding to changing expectations;

- Corporate crises which lead to new expectations and accountability requirements; or

- The profession attempting to control the direction and outcome of the expectation debate to maintain the status quo (Shaikh and Talha, 2003). 
The Canadian Institute of Chartered Accountants (1988) sponsored a study on the public's expectations of audit (the MacDonald Report). The commission developed a detailed audit expectation gap model that analyzed the individual components of the expectation gap into unreasonable expectation, deficient performance and deficient standard, this model presented in Figure 1.

Figure 1. Components of the audit expectations gap

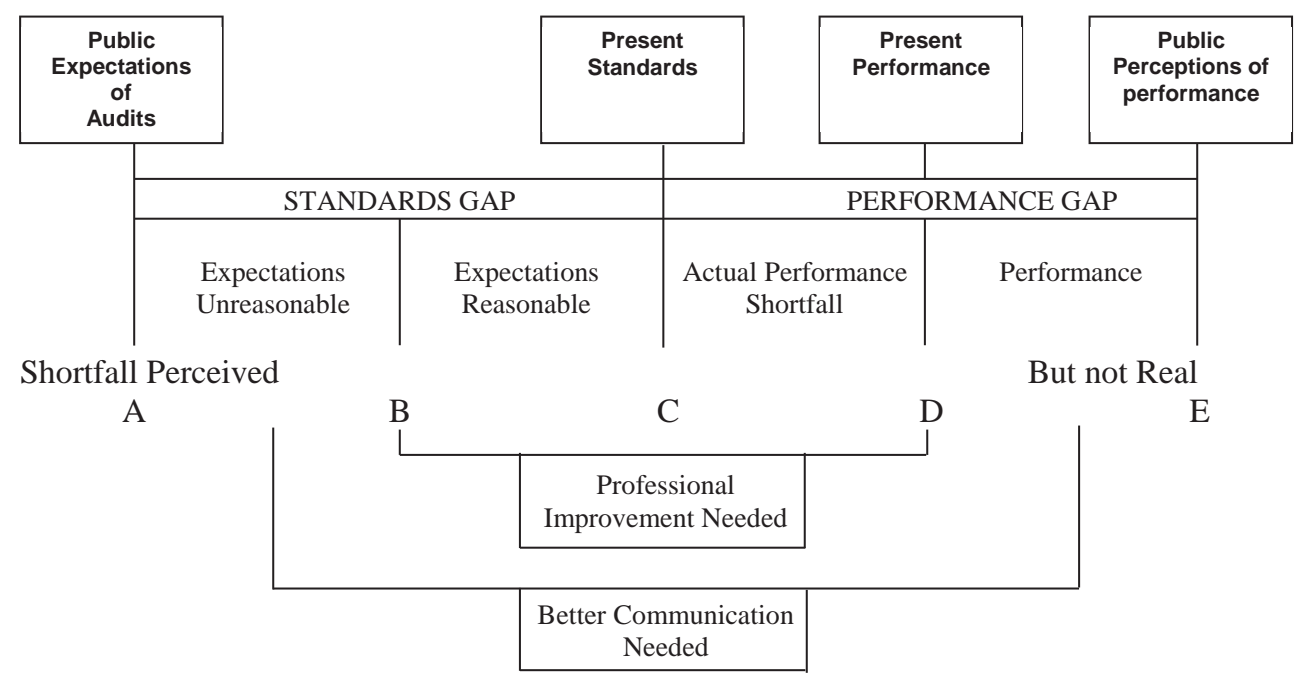

Notes on Figure 1:

The figure represents the full gap possible between the highest expectations of audits (point A) to public perceptions of what audits actually seem to provide (point E). Point $\mathrm{C}$ represents auditor performance and financial information quality called for by present standards. The line segment $\mathrm{A}$ to $\mathrm{C}$ represents public expectations that go beyond existing auditing and accounting standards. The line segment $\mathrm{C}$ to $\mathrm{E}$ represents public perceptions that auditor performance or audited financial information falls short of what is required by existing standards.

Source: Adapted from MacDonald Commission (1988: 23).

Based on this figure, three components of the expectation gap can be identified as follows:

(1) Reasonableness gap: A gap between what the society expect auditors to achieve and what they can reasonably be expected to accomplish. Such a gap exists because of misunderstanding of users, users' over expectations, uneducated users, miscommunication of users, miss-interpretation of users and unawareness of users from the audit practice limitations.

(2) Deficient standards gap: A gap between the duties, which can reasonably be expected of auditors, and auditors existing duties as defined by law and professional promulgations. Kinney (1993) states that one of the major causes of the profession's 
expectation gap is the difference between what the standards of the profession provide and what users might desire. In addition, such a gap existed because of lack of sufficient standards to covering all of audit practices or the existence of the insufficient standards for audit responsibilities, detection of fraud and illegal acts. In short, the deficient standards gap is only because of insufficient or poor standards to audit functions.

Figure 2. Reasons of audit expectation gap

Perceived performance Gap Society's expectation of auditors

\begin{tabular}{|c|c|c|c|c|}
\hline Performance gap & Standard gap & \multicolumn{3}{|c|}{ Reasonableness gap } \\
\hline \multirow{2}{*}{$\begin{array}{l}\text { Reasonable } \\
\text { expectation } \\
\text { of auditor } \\
\text { performance }\end{array}$} & \multirow{2}{*}{$\begin{array}{l}\text { Reasonable expectation } \\
\text { of standard }\end{array}$} & \multicolumn{3}{|c|}{ Unreasonable expectations } \\
\hline & & $\begin{array}{l}\text { Over- expectation } \\
\text { of audit } \\
\text { performance }\end{array}$ & \begin{tabular}{|l|} 
Over- \\
expectation of \\
standards
\end{tabular} & $\begin{array}{l}\text { Miscommunication } \\
\text { of users }\end{array}$ \\
\hline \multicolumn{5}{|c|}{ Reasons of Audit Expectation Gap } \\
\hline $\begin{array}{ll}\text { o } & \text { Non- audit service } \\
\text { practicing by auditors } \\
\text { o } & \text { Self-interest and } \\
\text { economical benefits of } \\
\text { auditors } \\
\text { o } \\
\text { o } \text { Depualified auditor } \\
\text { o } & \text { Miscommunication of } \\
& \text { auditors }\end{array}$ & \begin{tabular}{|ll} 
o & Lack of sufficient \\
& standards \\
o & Existing insufficient \\
& standards regarding \\
& auditor responsibilities \\
for detection of fraud \\
and illegal acts
\end{tabular} & \multicolumn{3}{|c|}{$\begin{array}{ll}\text { o } & \text { Misunderstanding of users } \\
\text { o } & \text { Over expectations of users to auditor performances } \\
\text { o } & \text { Misinterpretation of users } \\
\text { o } & \text { Unawareness users of audit responsibilities and } \\
& \text { limitations } \\
\text { o } & \text { Users' over expectation of standards }\end{array}$} \\
\hline
\end{tabular}

Source: Salehi, Mahdi (2007:59).

(3) Deficient performance gap: A gap between the expected standard of performance of auditors existing duties, and performance as expected and perceived by society (Porter et al., 2003). Such a gap also confirmed by scholars and researchers in many countries. The main reasons of such a gap may be classified as follows: Non-audit services practicing by auditors, self-interesting auditors and economical relationship with clients, unqualified auditors, and dependent auditors. Several reasons of audit expectation gap showed in figure 2 .

Defliese et al. (1988) point out that it is important to appraise the realism of public expectations and perceptions when the profession seeks remedies to the expectation gap. If the reasonable expectations of the public are not met by the existing professional standards or the profession's performance falls short of its standards, the standards and/or the performance should be improved. However, if the public has unreasonable expectations or their perceptions of performance are mistaken, the profession should 
attempt to improve the public understanding. It is the professional bodies, and legal responsibility to determine the auditors' responsibility to achieve the reasonable public expectations. Monroe and Woodliff (1994) and Woodliff (1995) pointed out that one of the components of the expectation gap is the difference between the expectations of users and the reasonable standard of auditing which the auditing profession can be expected to deliver (unreasonable expectations gap).

The debate about the audit expectation gap consistently centers on a number of perennial issues. Three major ones are: (a) The nature and meaning of audit report messages; (b) Early warning by auditors of corporate failure; and (c) The auditor's responsibility for the detection and reporting of fraud.

A study carried out by the Institute of Chartered Accountants of Scotland found that users expect audited financial reports to provide them with assurance (Gill \& Cosserat, 1996:131) that: The financial statements are right; the company will not fail; there has been no fraud; the company has acted within the law; the company has been competently managed; and the company has adopted a responsible attitude to environmental and societal matters.

Furthermore the study found that users expect the independent auditor to be:

o Independent of the directors of the company being audited;

o Responsible for reporting to a third party (shareholders) if they suspect that the directors are involved in fraud or other illegal acts;

o Accountable to a wide range of stakeholders; and to be financially liable if they fail in any of their duties.

The users of the audit report should understand that audits are carried out in accordance with prescribed standards and provide them with an opportunity to review those standards for themselves. It is the law makers' responsibility whether that is the legislator or the courts to determine whether these standards are adequate.

\section{Research Methodology}

The main method of research on the audit expectations gap has been the questionnaire using a Likert's scale (Beasley, 1996). Survey-based empirical studies fail to conduct deeper analysis of the reasons behind the expectations gap; therefore, Fivepoint likert's scale questionnaire instrument was employed in this research while the questionnaire consisted of two sections. The first section contained data relating to demographic variables of the sample respondents and the second section contained the perceptions of sample respondents on the actual level and the expected level of audit effectiveness. The respondents were required to tick their perceptional levels on five-point Likert's scale with ' 5 ' as strongly agree, '4' as agree, '3' as moderately agree, ' 2 ' as disagree and ' 1 ' as strongly disagree for both the actual level and the 
expected level. Sufficient space provided for giving comments and suggestions at the end of the questionnaire.

These pre-test steps for questionnaire were followed. A rough pilot questionnaire was developed. Concepts were discussed and debated and wordings were changed as necessary. The order of some of the statements was also changed. Some questions were eliminated because they appeared redundant. Consequently some additional statements were added. In reviewing the statements, some statements were felt to contain more than one concept. So in those cases the statements were revised into separate statements to allow for different responses to each concept. The second phase of the pre-test was the administration of the revised survey to respondents, who were informed that this was a pre-test and specifically asked about questionnaire. Feedback was revised on the effect of the original format. This revised survey was gone over carefully and revisions were made before the final administration of the final questionnaire.

In order to analyzing data, non-parametric Mann-U Whitney test will be employed and at the end of the paper, the audit expectation gap will be quantified.

\section{The Empirical Results}

Totally 600 questionnaires are distributed between 300 Certified accountants and 300 professional investors in Iran during 1-03-2012 up to 30-05-2012. Out of 600 questionnaires only 320 usable questionnaire are collected. The rate of returned questionnaire stood at $53.33 \%$. Table 1 shows the details of the both responds groups.

Table 1. Rate of returned questionnaire

\begin{tabular}{|l|c|c|c|}
\hline Participants & Distributed Questionnaire & Returned Questionnaire & Percent \\
\hline Auditors & 300 & 195 & 65.00 \\
\hline Investors & 300 & 125 & 41.67 \\
\hline Total & 600 & 320 & 53.33 \\
\hline
\end{tabular}

In this part audit expectation gap about the auditors' responsibilities will be test according to non-parametric test in order to identifying the expectation gap. Auditors' responsibilities consider as (a) auditors' responsibility in measuring financial performance, (b) auditors' responsibility in financial control, (c) auditors' responsibility in finding misstatement and (d) professional discipline of auditors.

\section{(a) Auditors' Responsibility in Measuring Financial Performance}

Table 2 presents the statistical result of perceptions on auditors and investors on the responsibilities of auditors in measuring financial performance. There were signif- 
icant differences in the perceptions between auditors and investors for both actual and expected levels with respect to producing the financial statements, conducting of cent percent examination in audit procedure and giving assurance that company is in good financial health. It showed that there was an expectation gap between auditors and investors. The grand mean values assigned were 2.12 by auditors and 2.57 by investors at actual level of performance indicating low responsibility and with the expected level of investors with the value of 3.75. However, expected level of grand mean value assigned by the auditors stood at 2.30 indicating that there was further expectation among the auditors regarding the auditors' responsibilities in measuring financial performance. The expectation gap was perceived to be lower with a difference in mean values of auditors and investors at actual level with 0.45 and it was perceived at higher level at expected level from auditors and investors with a difference in mean value of 1.45. The Mann-Whitney U Test showed that there were significant difference between the perception of the auditor and investor among the expected levels of producing the statements and both the levels of cent per cent examination and giving assurance $(\mathrm{Z}=<0.05)$. However, there was no significant difference between the perception of auditor and investor in actual level of producing statement $(Z=>0.05)$.

Table 2. Auditors' responsibility in measuring financial performance: auditors vs. investors

\begin{tabular}{|c|c|c|c|c|c|c|c|c|c|}
\hline \multirow{2}{*}{$\begin{array}{l}\dot{z} \\
\dot{\pi}\end{array}$} & \multirow{2}{*}{$\begin{array}{l}\text { Level of Auditors' } \\
\text { Responsibility in }\end{array}$} & \multirow{2}{*}{ 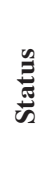 } & \multirow{2}{*}{ 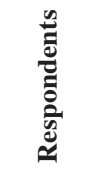 } & \multicolumn{3}{|c|}{ Group Statistics } & \multirow{2}{*}{$\begin{array}{c}\begin{array}{c}\text { Paired } \\
\text { Differences }\end{array} \\
\text { Mean }\end{array}$} & \multicolumn{2}{|c|}{ Tests** } \\
\hline & & & & Median & Mean & SD & & $\begin{array}{l}\text { Mann-U } \\
\text { Whitney }\end{array}$ & $\mathbf{Z}^{*}$ \\
\hline \multirow{4}{*}{1} & \multirow{4}{*}{$\begin{array}{l}\text { Producing the financial } \\
\text { statements }\end{array}$} & \multirow{2}{*}{ A } & AU-195 & 2 & 2.40 & 0.842 & \multirow{2}{*}{-0.13} & \multirow{2}{*}{-1.345} & \multirow{2}{*}{0.179} \\
\hline & & & $\mathrm{I}-125$ & 3 & 2.53 & 1.216 & & & \\
\hline & & \multirow{2}{*}{$\mathrm{E}$} & AU-195 & 2 & 2.44 & 1.182 & \multirow{2}{*}{-1.54} & \multirow{2}{*}{-11.207} & \multirow{2}{*}{0.000} \\
\hline & & & $\mathrm{I}-125$ & 4 & 3.98 & 1.176 & & & \\
\hline \multirow{4}{*}{2} & \multirow{4}{*}{$\begin{array}{l}\text { Conduct of } 100 \% \\
\text { examination in audit } \\
\text { procedure }\end{array}$} & \multirow{2}{*}{ A } & AU-195 & 1 & 1.63 & 1.134 & \multirow{2}{*}{-0.87} & \multirow{2}{*}{-8.398} & \multirow{2}{*}{0.000} \\
\hline & & & I-125 & 2 & 2.50 & 1.193 & & & \\
\hline & & \multirow{2}{*}{$\mathrm{E}$} & AU-195 & 1 & 1.88 & 1.44 & \multirow{2}{*}{-1.53} & \multirow{2}{*}{-10.194} & \multirow{2}{*}{0.000} \\
\hline & & & $\mathrm{I}-125$ & 4 & 3.41 & 1.373 & & & \\
\hline \multirow{4}{*}{3} & \multirow{4}{*}{$\begin{array}{l}\text { Giving assurance that } \\
\text { company is in good } \\
\text { financial health }\end{array}$} & \multirow{2}{*}{ A } & AU-195 & 2 & 2.33 & 0.826 & \multirow{2}{*}{-0.35} & \multirow{2}{*}{-3.227} & \multirow{2}{*}{0.001} \\
\hline & & & $\mathrm{I}-125$ & 3 & 2.68 & 1.238 & & & \\
\hline & & \multirow{2}{*}{$\mathrm{E}$} & AU-195 & 2 & 2.56 & 1.072 & \multirow{2}{*}{-1.32} & -10.341 & 0.000 \\
\hline & & & $\mathrm{I}-125$ & 4 & 3.88 & 1.279 & & -10.341 & 0.000 \\
\hline & & $\Delta$ & AU-195 & 1.67 & 2.12 & & 0 & & \\
\hline & $\mathrm{Gr}_{\mathrm{r}}$ & A & I-125 & 2.67 & 2.57 & & -0.45 & & \\
\hline & & $\mathbf{F}$ & AU-195 & 1.67 & 2.30 & & 1 & & \\
\hline & & $\mathbf{E}$ & I-125 & 5.33 & 3.75 & & -1.40 & & \\
\hline
\end{tabular}

*Significance (2-tailed), Note: AU = Auditors, $\mathrm{I}=$ Investors, $\mathrm{A}=$ Actual, $\mathrm{E}=$ Expectation 


\section{(b) Auditors' Responsibility in Financial Control}

Table 3 depicts the results of perceptions of auditors and investors on auditors' responsibility in financial control. The levels of responsibility measured were maintaining accounting records by the management, safeguarding the assets of the company and prevention of errors and frauds. The grand mean values at actual level assigned by auditors and investors stood at 2.30 and 2.74 respectively. At the expected level, auditors assigned little more value of 2.70 whereas the investors expected moderately high by assigning the value of 3.81. Auditors assigned highest mean value at actual level with a value of 4.44 for maintaining accounting records by management, but investors' assigned low mean value of 2.70. At the expected level, auditors assigned highest value of 3.94 and investors also expected moderately high by assigning the value of 3.70. For safeguarding the assets of the company, auditors at actual level assigned 2.37 but investors assigned more value at 2.87. At expected level, auditors assigned 2.61 but the investor expected moderately high and the value stood at 3.76 . Regarding auditor responsibility in the prevention of frauds and errors, auditors at actual level assigned the value of 2.18 and investors assigned at 2.66. Nevertheless, at expected level, auditors assigned very low value of 1.56 but the investors' expectation

Table 3. Auditors' responsibility in financial control

\begin{tabular}{|c|c|c|c|c|c|c|c|c|c|}
\hline \multirow{2}{*}{$\begin{array}{l}\dot{\mathrm{z}} \\
\dot{\vec{n}}\end{array}$} & \multirow{2}{*}{$\begin{array}{l}\text { Level of Auditors' } \\
\text { Responsibility in }\end{array}$} & \multirow{2}{*}{$\stackrel{\mathscr{E}}{\frac{\mathscr{E}}{\omega}}$} & \multirow{2}{*}{ 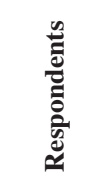 } & \multicolumn{3}{|c|}{ Group Statistics } & \multirow{2}{*}{$\begin{array}{c}\text { Paired } \\
\text { Differences }\end{array}$} & \multicolumn{2}{|c|}{ Tests** } \\
\hline & & & & Median & Mean & SD & & $\begin{array}{l}\text { Mann-U } \\
\text { Whitney }\end{array}$ & $\mathbf{Z}^{*}$ \\
\hline \multirow{4}{*}{1} & \multirow{4}{*}{$\begin{array}{l}\text { Maintaining } \\
\text { accounting records } \\
\text { by the management }\end{array}$} & \multirow{2}{*}{ A } & AU-195 & 5 & 4.44 & 1.038 & \multirow{2}{*}{1.74} & \multirow{2}{*}{-13.227} & \multirow{2}{*}{0.000} \\
\hline & & & $\mathrm{I}-125$ & 3 & 2.70 & 1.276 & & & \\
\hline & & \multirow{2}{*}{$\mathrm{E}$} & AU-195 & 4 & 3.94 & 0.713 & \multirow{2}{*}{0.24} & \multirow{2}{*}{-0.439} & \multirow{2}{*}{0.661} \\
\hline & & & I- 125 & 4 & 3.70 & 1.392 & & & \\
\hline \multirow{4}{*}{2} & \multirow{4}{*}{$\begin{array}{l}\text { Safeguarding the } \\
\text { assets of the company }\end{array}$} & \multirow{2}{*}{ A } & AU-195 & 2 & 2.37 & 0.822 & \multirow{2}{*}{-0.5} & \multirow{2}{*}{-4.771} & \multirow{2}{*}{0.000} \\
\hline & & & I- 125 & 3 & 2.87 & 1.275 & & & \\
\hline & & \multirow{2}{*}{ E } & AU-195 & 2 & 2.61 & 1.104 & \multirow{2}{*}{-1.15} & \multirow{2}{*}{-8.553} & \multirow{2}{*}{0.000} \\
\hline & & & I- 125 & 4 & 3.76 & 1.3922 & & & \\
\hline \multirow{4}{*}{3} & \multirow{4}{*}{$\begin{array}{l}\text { Prevention of frauds } \\
\text { and errors }\end{array}$} & \multirow{2}{*}{ A } & AU-195 & 2 & 2.18 & 0.53 & \multirow{2}{*}{-0.48} & \multirow{2}{*}{-5.042} & \multirow{2}{*}{0.000} \\
\hline & & & $\mathrm{I}-125$ & 3 & 2.66 & 1.158 & & & \\
\hline & & \multirow{2}{*}{ E } & AU-195 & 1 & 1.56 & 1.128 & \multirow{2}{*}{-2.42} & 15040 & 0000 \\
\hline & & & I- 125 & 4 & 3.98 & 1.206 & & -115.042 & 0.000 \\
\hline & & $\mathbf{A}$ & AU-195 & 3 & 2.30 & & 042 & & \\
\hline & & A & I-125 & 3 & 2.74 & & -0.42 & & \\
\hline Gra & ad Mean & $\mathbf{A}$ & U-195 & 2.33 & 2.70 & & & & \\
\hline & & $\mathbf{E}$ & I-125 & 4 & 3.81 & & -1.11 & & \\
\hline
\end{tabular}

*Significance (2-tailed), Note: AU = Auditors, I = Investors, A = Actual, E = Expectation 
was high with a value of 3.98. The expectation gap was high in this area with a mean difference of 2.42. The test showed that there were significant differences between the perceptions of the auditors and investors among the actual level of records maintained by management and both the level of safeguarding assets and prevention of frauds and errors $(Z<0.05)$; but there was no significant difference between the perception of both the groups of respondents on the expected level with regard to records maintained by management $(\mathrm{Z}>0.05)$.

\section{(c) Auditors' Responsibility in Finding Misstatement}

Table 4 shows the perceptions of investors and auditors in auditors' responsibility in finding financial misstatement. The auditors assigned the actual grand mean value of 2.96 and investors assigned the mean value of 2.47 with a lower weightage and expectation gap of 0.49 was found. At expected level, the auditors and investors recognized

Table 4. Auditors' responsibility in financial misstatement

\begin{tabular}{|c|c|c|c|c|c|c|c|c|c|}
\hline \multirow{2}{*}{$\begin{array}{l}\dot{z} \\
\dot{\vec{s}}\end{array}$} & \multirow{2}{*}{$\begin{array}{l}\text { Level of Auditors' } \\
\text { Responsibility in }\end{array}$} & \multirow{2}{*}{ 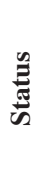 } & \multirow{2}{*}{ 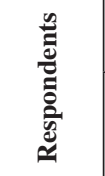 } & \multicolumn{3}{|c|}{ Group Statistics } & \multirow{2}{*}{$\begin{array}{c}\begin{array}{c}\text { Paired } \\
\text { Differences }\end{array} \\
\text { Mean }\end{array}$} & \multicolumn{2}{|c|}{ Tests** } \\
\hline & & & & Median & Mean & SD & & $\begin{array}{l}\text { Mann-U } \\
\text { Whitney }\end{array}$ & $\mathbf{Z}^{*}$ \\
\hline \multirow{4}{*}{1} & \multirow{4}{*}{$\begin{array}{l}\text { Enforcing effectiveness } \\
\text { of internal control on } \\
\text { audit quality }\end{array}$} & \multirow{2}{*}{ A } & AU-195 & 2 & 2.38 & 0.8405 & \multirow{2}{*}{-0.18} & \multirow{2}{*}{-1.733} & \multirow{2}{*}{0.083} \\
\hline & & & I-125 & 3 & 2.56 & 1.223 & & & \\
\hline & & $\mathrm{E}$ & AU-195 & 2 & 2.61 & 1.051 & 008 & 7710 & 0000 \\
\hline & & $\mathrm{E}$ & I-125 & 4 & 3.59 & 1.373 & -0.90 & -1.110 & 0.000 \\
\hline \multirow{4}{*}{2} & \multirow{4}{*}{$\begin{array}{l}\text { Detecting illegal acts by } \\
\text { the management }\end{array}$} & \multirow{2}{*}{ A } & AU-195 & 5 & 4.25 & 1.273 & \multirow{2}{*}{1.75} & \multirow{2}{*}{-12.474} & \multirow{2}{*}{0.000} \\
\hline & & & $\mathrm{I}-125$ & 3 & 2.50 & 1.236 & & & \\
\hline & & \multirow{2}{*}{$\mathrm{E}$} & AU-195 & 5 & 4.57 & 0.99 & \multirow{2}{*}{0.78} & \multirow{2}{*}{-7.359} & \multirow{2}{*}{0.000} \\
\hline & & & $\mathrm{I}-125$ & 4 & 3.79 & 1.405 & & & \\
\hline \multirow{4}{*}{3} & \multirow{4}{*}{$\begin{array}{l}\text { Reporting all detected } \\
\text { frauds and thefts to the } \\
\text { relevant authority }\end{array}$} & \multirow{2}{*}{ A } & AU-195 & 4 & 3.54 & 1.027 & \multirow{2}{*}{1.21} & \multirow{2}{*}{-9.895} & \multirow{2}{*}{0.000} \\
\hline & & & $\mathrm{I}-125$ & 2 & 2.33 & 1.291 & & & \\
\hline & & \multirow{2}{*}{$\mathrm{E}$} & AU-195 & 4 & 3.83 & 0.802 & \multirow{2}{*}{0.15} & \multirow{2}{*}{-0.803} & \multirow{2}{*}{0.422} \\
\hline & & & $\mathrm{I}-125$ & 4 & 3.68 & 1.381 & & & \\
\hline & & A & AU-195 & 1 & 1.66 & 1.164 & -085 & -8109 & 0000 \\
\hline 4 & Detecting any deliberate & A & $\mathrm{I}-125$ & 2 & 2.51 & 1.193 & -0.85 & -8.109 & 0.000 \\
\hline 4 & $\begin{array}{l}\text { information } \\
\text { intal }\end{array}$ & $\mathrm{E}$ & AU-195 & 1 & 1.91 & 1.49 & 84 & -11711 & 0.000 \\
\hline & & & I-125 & 4 & 3.75 & 1.366 & 54 & & \\
\hline & & $\Delta$ & AU-195 & 3 & 2.96 & & 040 & & \\
\hline & & A & I-125 & 2.5 & 2.47 & & 0.49 & & \\
\hline & Grand Mean & $\mathbf{A}$ & U-195 & 3 & 3.23 & & & & \\
\hline & & $\mathbf{E}$ & I-125 & 4 & 3.69 & & -0.46 & & \\
\hline
\end{tabular}

*Significance (2-tailed), Note: AU = Auditors, I = Investors, A = Actual, E = Expectation 
the responsibility by assigning a higher weightage with an expected mean value of 3.23 and 3.69 respectively with a gap of 0.46 . This implied that the auditors and investors were expecting more responsibility from auditors in reducing financial misstatement. Auditors' responsibility in financial misstatement for detecting illegal acts by the management, the auditors assigned the highest mean value at actual level with 4.25, whereas investors assigned mean values of 2.50 and at expected level also auditors' assigned highest value with 4.57 and investors with 3.79 . Regarding the responsibility of detecting any deliberate distortion of financial information auditors assigned very low mean value of 1.66, but investors assigned lower mean value of 2.51. At expected level also, auditors assigned a mean value of 1.91 and investors assigned a value of 3.75 . The expectation gap was also highest in this area with a mean difference of 1.84 .

The test showed that there were significant differences between the perception of the auditors and investors among the expected level of effectiveness of internal control, the actual level of reporting all detected frauds and thefts to the relevant authority and both level of detecting illegal acts by the management and detecting any deliberate distortion of financial information $(Z<0.05)$. But there were no significant differences between the perception of both the groups of respondents on the actual level of effectiveness of internal control on audit quality and expected level of detected frauds and thefts to the relevant authority $(\mathrm{Z}>0.05)$.

\section{(d) Professional Discipline of Auditors}

Table 5 presents the results of perceptions of the respondents about the auditors' responsibility towards professional discipline. At actual level of grand mean value, auditors assigned a moderate mean value of 3.05 and the investors assigned a lower mean value of 2.60 with regard to the auditors' responsibility towards professional discipline with an expectation gap of 0.45 . Regarding the expected level of grand mean auditors and investors assigned a moderate mean value of 3.12 and 3.76 respectively with a gap of 0.64 . Auditors' responsibility towards professional discipline were studied in three areas; namely, detection of frauds and errors, right procedure followed before authenticating financial statements and certifying accuracy of financial statements. At grand mean level, auditors perceived the professional discipline of auditors at a moderate level by assigning the actual value of 3.05 and at expected level, it was 3.12, whereas investors at actual level assigned low value of 2.60 and at expected level, it was 3.76. It was observed that the auditors assigned the actual mean value of 3.70 towards auditors' responsibility regarding to right procedure followed before authenticating financial statements and at expected level, they assigned the mean value of 3.99. The investors assigned highest mean value of 2.88 at actual level towards responsibility of auditors in certifying accuracy of financial reports. Nevertheless, investors expected more responsibility of auditors in detection of frauds and 
errors by assigning the mean value of 3.98 at expected level. The expectation gap was high in auditors' responsibility in detection of frauds and errors at expected level with a difference of 1.62. The tests showed that there were significant differences between the perceptions of auditors and investors on both the actual and expected levels for all the variables include in professional disciplines $(\mathrm{Z}=<0.05)$.

Table 5. Professional discipline of auditors

\begin{tabular}{|c|c|c|c|c|c|c|c|c|c|}
\hline \multirow{2}{*}{$\begin{array}{l}\dot{\dot{z}} \\
\dot{\tilde{n}}\end{array}$} & \multirow{2}{*}{$\begin{array}{l}\text { Level of Auditors' } \\
\text { Responsibility in }\end{array}$} & \multirow{2}{*}{ 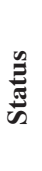 } & \multirow{2}{*}{ 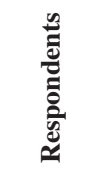 } & \multicolumn{3}{|c|}{ Group Statistics } & \multirow{2}{*}{$\begin{array}{c}\text { Paired } \\
\text { Differences } \\
\text { Mean }\end{array}$} & \multicolumn{2}{|c|}{ Tests** } \\
\hline & & & & Median & Mean & SD & & $\begin{array}{l}\text { Mann-U } \\
\text { Whitney }\end{array}$ & $\mathbf{Z}^{*}$ \\
\hline \multirow{4}{*}{1} & \multirow{4}{*}{$\begin{array}{l}\text { Detection of frauds and } \\
\text { errors }\end{array}$} & \multirow{2}{*}{ A } & AU-195 & 2 & 2.27 & 0.694 & \multirow{2}{*}{-0.28} & \multirow{2}{*}{-2.025} & \multirow{2}{*}{0.043} \\
\hline & & & $\mathrm{I}-125$ & 2 & 2.55 & 1.242 & & & \\
\hline & & \multirow{2}{*}{$\mathrm{E}$} & AU-195 & 2 & 2.36 & 1.047 & \multirow{2}{*}{-1.62} & \multirow{2}{*}{-11.988} & \multirow{2}{*}{0.000} \\
\hline & & & $\mathrm{I}-125$ & 4 & 3.98 & 1.242 & & & \\
\hline \multirow{4}{*}{2} & \multirow{4}{*}{$\begin{array}{l}\text { Right procedures } \\
\text { followed before } \\
\text { authenticating financial } \\
\text { statements }\end{array}$} & \multirow{2}{*}{ A } & AU-195 & 4 & 3.70 & 0.808 & \multirow{2}{*}{1.31} & \multirow{2}{*}{-12.07} & \multirow{2}{*}{0.000} \\
\hline & & & $\mathrm{I}-125$ & 2 & 2.39 & 1.172 & & & \\
\hline & & \multirow{2}{*}{$\mathrm{E}$} & AU-195 & 4 & 3.99 & 0.606 & \multirow{2}{*}{0.56} & \multirow{2}{*}{-4.229} & \multirow{2}{*}{0.000} \\
\hline & & & $\mathrm{I}-125$ & 4 & 3.43 & 1.304 & & & \\
\hline \multirow{4}{*}{3} & \multirow{4}{*}{$\begin{array}{l}\text { Certifying accuracy of } \\
\text { financial reports }\end{array}$} & \multirow{2}{*}{ A } & AU-195 & 3 & 3.17 & 0.657 & \multirow{2}{*}{0.29} & \multirow{2}{*}{-2.366} & \multirow{2}{*}{0.018} \\
\hline & & & $\mathrm{I}-125$ & 3 & 2.88 & 1.227 & & & \\
\hline & & \multirow{2}{*}{$\mathrm{E}$} & AU-195 & 3 & 3.29 & 0.783 & \multirow{2}{*}{-0.58} & 7015 & \\
\hline & & & $\mathrm{I}-125$ & 4 & 3.87 & 1.314 & & -1.015 & 0.000 \\
\hline & & $\mathbf{A}$ & AU-195 & 3 & 3.05 & & 045 & & \\
\hline & Grand Mear & A & I-125 & 2.3 & 2.60 & & 0.45 & & \\
\hline & Grand ivean & $\mathbf{A}$ & U-195 & 3 & 3.12 & & -0.64 & & \\
\hline & & $\mathbf{E}$ & I-125 & 4 & 3.76 & & & & \\
\hline
\end{tabular}

*Significance (2-tailed), Note: AU = Auditors, I = Investors, A = Actual, E = Expectation

\section{Porter's Model}

The present study uses the Porter's model (1993: 50) to measure the audit expectation gap in Iran. According to her, the audit expectation performance gap is defined as the gap between society's expectation of auditors and auditor's performance, as perceived by the society.

\section{The Components of the Model}

Given the definition, the analysis indicates that the gap has two major components: (1) A gap between what society expects auditors to achieve and what they can rea- 
sonably be expected to accomplish (designated as reasonableness gap), and (2) A gap between what society can reasonably expect auditors to accomplish and what they are perceived to achieve (designated performance gap). This may be subdivided into: (a) a gap between the duties, which can reasonably be expected of auditors and auditors' existing duties as defined by the law and professional promulgations ('deficient standards'); and (b) a gap between the expected standard of performance of auditors' existing duties and auditors' perceived performance, as expected and perceived by society ('deficient performance').

An overview of these deficiencies in audit, also known as audit expectation gap, is depicted in the following Figure 3.

Figure 3. Structure of the audit expectation performance gap

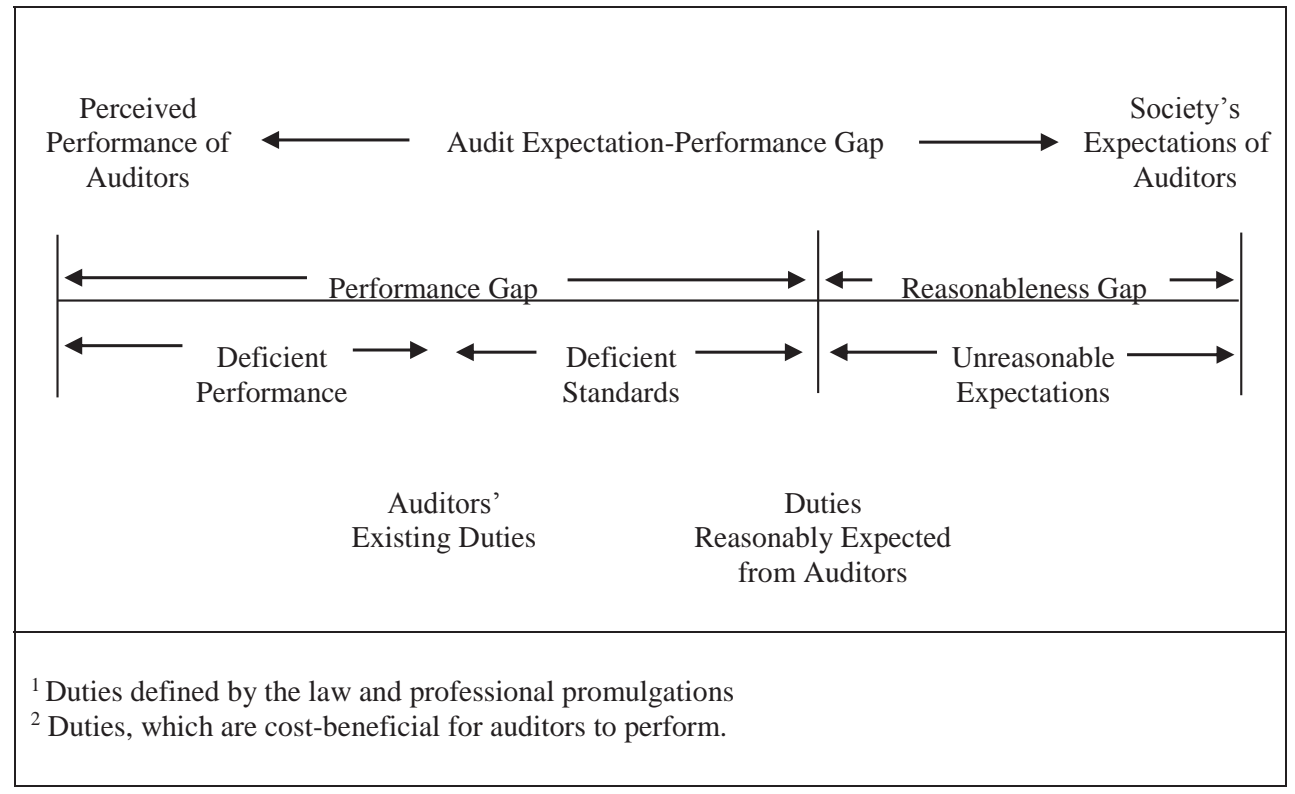

Source: Porter (1993: 50).

\section{Illustrating Porter's Model}

Table 6 highlights the Porter's Model of audit expectation gap, which consists of a comparison between the perceptions of actual and expected levels of audit by auditors and the society with the levels measured in terms of mean values. The figure presents the determination of audit expectation gap comprising of reasonableness gap and performance gap, the later consisting of deficient standards and deficient performance based on hypothetical mean values. 
Table 6. Illustrating Porter's model

\begin{tabular}{|l|c|c|}
\hline Respondents & Actual Level & Expected level \\
\hline Auditors & $2.50(\mathrm{~A})$ & $2.55(\mathrm{~B})$ \\
\hline Investors & $2.75(\mathrm{C})$ & $4.150(\mathrm{D})$ \\
\hline
\end{tabular}

Table 7 briefly summarizes the simplified version of calculating the different expectation gaps based on the Porter's Model.

Table 7. Determination of gaps

\begin{tabular}{|l|}
\hline A.E.G1=Investors' Expectation Minus Investors' Rating \\
\hline (1) R.G2 =Investors' Expectation Minus Auditors' Expectation \\
\hline (2) P.G3 = Investors' Rating Minus Auditors' Expectation \\
\hline (2.1) D.S4 = Auditors' Rating Minus Auditors' Expectation \\
\hline (2.2) D.P5 =Investors' Minus Auditors' Rating \\
\hline
\end{tabular}

Note1: Audit Expectation Gap; Note2: Reasonableness Gap;

Note3: Performance Gap; Note4: Deficient Standards; and

Note5: Deficient Performance.

Based on the information given in Table 6 and 7, the values of expectation gaps are presented in Table 8.

Table 8. Quantifying audit expectation gap

\begin{tabular}{|l|c|c|}
\hline Total of Gap & Mean Values Considered & Level of Gap \\
\hline A.E.G. & C Minus D & -1.40 \\
\hline (1) R.G. & D Minus B & 1.60 \\
(2) P.G. & C Minus B & 0.2 \\
(2.1)D.S. & A Minus B & -0.05 \\
\cline { 1 - 2 } (2.2)D.P. & C Minus A & 0.25 \\
\hline
\end{tabular}

Source: Tables 6 and 7.

Table 9 shows that out of total audit expectation gap (-1.40) 1.60 belongs to the reasonableness gap and -0.2 belongs to performance gap. About the performance gap in is subdivided into deficient performance gap (0.25) and deficient standard (-0.05).

\section{Conclusion}

Although, several studies have been conducted in different countries, even the most recent study conducted by Pourheydari and Abousaiedi (2011) in Iran. The prior study 
only focused on the existence of audit expectation gap and the areas of the gap. The current study covers the previous studies dimensions, even covers more dimension of the audit expectation gap, besides; it offers new approach in order to quantifying audit expectation gap in the world.

In not shell, audit is moving away from the private domain to the public domain resulting in the adoption of public interest concept. The spur for this phenomenon comes from corporate social responsibility and corporate governance, which are required to change the management style from self-interest to social interest. The medium through which this realization is to be achieved is to be founded on audit quality improvement. The players in this process consist of the accounting profession, the government, the corporate management and the general public. A concerted effort is to be strategically devised to bring in a paradigm shift in audit philosophy to improve the credibility of audit opinion thereby injecting credibility in financial reporting to be used by relevant decision makers. The only hope is to make auditors more responsible towards society, in which they thrive with respect by upholding the professional values.

In the current study, it is found that there is an expectation gap between auditors and investors in Iran. In order to at least reducing the gap the following steps may should be taken:

(i) Deficient standards gap should be reduced by introducing more stringent audit standards through amendments to the Companies Act in Iran;

(ii) Audit ethics should be imparted to all sections of society including the auditors;

(iii) The scope of financial reporting commitment should be enhanced by making auditors responsible for complete verification of the financial reporting process adopted by the management; and

(iv) The feasibility of mandatory implementation of audit rotation and peer review may be examined seriously to improve audit quality.

\section{REFERENCES}

AICPA (1993). Professional Standards, Vol. 1 and 2, New York: American Institute of Certified Public Accountants.

ASCPA / ICAA (1994). A Research Study on Financial Reporting and Auditing-Bridging the Expectation Gap.

Bailey, K.E., Joseph H., Bylinski and Michael D., Shields (1983). Effects of Audit Report Wording Changes on the Perceived Message, Journal of Accounting Research, Vol.21, No. 2, pp. 355-370.

Beasley, Mark S., (1996). An Empirical Analysis of the Relation between the Board of Director Composition and Financial Fraud, Accounting Review, Vol.71, pp.443-465.

Beelde, Ignace D., Sophine, Cooreman and Helmut, Leydens (1999). Expectations of Users of Financial Information with Regard to the Tasks Carried Out by Auditors, Available at: http:// scholar.google.com/scholar?hl=en\&lr=\&cluster $=8413614050073704063$ 
Canadian Institute of Chartered Accountants (1988). Report of The Commission to Study the Public's Expectations of Audits (MacDonald Commission), CICA, Toronto, Canada.

Chandler, Roy A., and John R., Edwards (1996). Recurring Issues in Auditing: Back to Future, Accounting, Auditing and Accountability, Journal, Vol.20, No. 2, pp. 4-29.

Cohen Commission (1978), Report of the Commission on Auditors' Responsibilities; Conclusions and Recommendations, New York: American Institute of Certified Public Accountants.

Darnill, Andrew (1991). The Profession and the Public, Accountancy, May, pp. 72-93.

Deegan, Craiy, and Michaela, Rankin (1999). The Environmental Reporting Expectations Gap: Australian Evidence, British Accounting Review, Vol. 31, No. 3, pp. 313-346.

Defliese, Patrick J., Murray B., Jaenicke, Henry R., O'Reilly and Philip L., Hirch (1988). Auditing. Eleventh Edition. John Wiley\&Sons.

Dejong, David V., and James H., Smith (1984). The Determination of Audit Responsibilities: on Application of Agency Theory, Auditing: A Journal of Practice and Theory, Vol. 4, No. 1, pp. 20-34.

Epstein, Marc J., and Marshall A., Geiger (1994). Investor Views of Audit Assurance: Recent Evidence of the Expectation Gap, Journal of Accountancy, January, pp.60-66.

Giacomino, D.E., (1994). Expanding the Auditor's Role to Narrow the Expectation Gap, Business Forum, Vol.17, No.2, pp.295-331.

Gill, Guadarshan S., and John W., Cosserat (1996). Modern Auditing in Australia, Fourth Edition, John Wiley \& Sons, Australia.

Godsell, David (1992). Legal Liability and the Audit Expectation Gap, Singapore Accountant, Vol. 8, November, pp. 25-28.

Guy, Dan M., and Jerry D., Sullivan (1988). The Expectation Gap Auditing Standards, Journal of Accountancy, Vol. 165, April, pp. 36-46.

Higson, Andrew (2003). Corporate Financial Reporting: Theory and Practice, London: SAGE Publications.

Hooks, Karen L., (1992). Professionalism and Self-interest: A Critical View of the Expectation Gap, Critical Perspective on Accounting, Vol.3, No. 2, pp. 109-136.

Humphrey, Christopher G., (1991). Audit expectations, in Current Issues in Auditing, London: Plul Chapma Publishing.

Humphrey, Christopher G., W.Stuart, Turley and Peter, Moizer (1993). Protecting Against Detection: The Case of Auditors and Fraud, Accounting, Organizations and Society, Vol.16, No. 4, pp. 313-331.

Jennings, Marianne M., Dan C., Kneer, and Philip M., Reckers (1993). The Significance of Audit Decision Aids and Pre-case Jurist's Attitude on Perceptions of Audit Firm Culpability and Liability, Contemporary Accounting Research, Vol. 9 No.2, pp.489-507.

Kelly, William A., and Lawrence C., Mohrweis (1989). Banker's and Investors' Perception of the Auditor's Role in Financial Statement Reporting: the Impact of SAS No. 58, Auditing: A Journal of Practice \& Theory, Vol. 9 pp.87-97.

Kinney, William R., (1993). Auditor Liability: Opportunities for Research, Journal of Economics and Management Strategy, Vol.2, pp.349-360.

Liggio, Carel D., (1974). The Expectation Gap: The Accountant's Waterloo, Journal of Contemporary Business, Vol.3, No.3, pp.27-44.

Martinis, Michael, Erming, Kim and Aw, Amy (2000). An Examination of the Audit Expectation Gap in Singapore, Asian Review of Accounting, Volume 8, No.1, pp.59-82.

Monroe, Gary S., and David R., Woodliff (1993). The Effect of Education on the Audit Expectation Gap, Accounting and Finance, Vol.33, No.1, pp. 61-78.

Monroe, Gary S., and David R., Woodliff (1994). An Empirical Investigation of the Audit Expectation Gap: Australian Evidence, Accounting and Finance, May, pp. 47-74. 
Murphy, Prisecilla, and Michael L., Maynard (1996). Using Judgment Profiles to Compare Advertising Agencies' and Clients' Campaign Values, Journal of Advertising Research, Vol. 36, No. 2, pp.19-27.

Percy, Lan (2007). Fifteen Years of Reformation What Next?, Managerial Auditing Journal, Vol.22, No.2, pp.226-235.

Porter, Brenda A., (1993). An Empirical Study of the Audit Expectation-Performance Gap, Accounting and Business Research, Vol. 24, No.93, pp. 49-68.

Porter, Brenda A., John, Simon and David, Hatherly (2003). Principles of External Auditing (2 end Edition), West Sussex, UK; John Wiley and Sons.

Pourheydari, O., and Mina Abousaiedi, (2011) "An empirical investigation of the audit expectations gap in Iran", Journal of Islamic Accounting and Business Research, Vol. 2 Iss: 1, pp.63 - 76

Salehi, Mahdi (2007). Reasonableness of Audit Expectation Gap: Possible Approach to Reducing, The Journal of Audit Practice, Vol. IV, No. 3, pp.50-59.

Shaikh, Junaid M., and Mohammad, Talha (2003). Credibility and Expectation Gap in Reporting on Uncertainties, Managerial Auditing Journal, Vol. 118, No.6/7, pp. 517-529.

Sikka, Prem N., Tony, Puxty, Hugh C., Willmott and Christine, Cooper (1998). The Impossibility of Eliminating the Expectation Gap: Some Theory and Evidence, Critical Perspectives on Accounting, Vol.9, No.3, pp.299-330.

Sikka, Prem N., Tony, Puxty, Hugh C., Willmott and Christine, Cooper (1992). Eliminating the Expectations Gap? ACCA-Research Report, No.28: London.

Singh, Rajiv K., (2004). Bridging All the Expectation Gap-The Changing Role of Concurrent Auditors, Available at: icai.org/icairoot/publications/complimentary/cajournal_may04/p1201-07.pdf -

Singleton Brain G., (1990). Bridging the Expectation Gap, Accountancy, October, pp. 79-84.

Trauth, Eileen M., Douglas W., Farwell, and Denis M., Lee (1993). The ISO Expectation Gap: Industry Expectations Vs. Academic Preparation, MIS: Quarterly, Vol.17, No.3, pp. 47-72.

Tricker, Bob R., (1982). Corporate Accountability and the Role of the Audit Function, in Hopwood, A. G., Bromehich, M. and Shaw, J. (eds), Auditing Research: Issues and Opportunities, London: Pitman Books.

Tweedie, David (1987). Challenges Facing the Auditors: Professional Fouls and the Expectation Gap, The Deloitt, Haskins and sells Lecture, University College, Cardiff, April 30, 1987.

Woodliff, David R., (1995). An Empirical Investigation of Audit Expectation Gap, Unpublished PhD Thesis, University of Western Australia. 